\title{
視床下部神経分泌細胞における放出ホルモンの 分泌調節機序に関する研究
}

II. 神経分泌細胞の神経性調節と化学伝達物質について 横浜市立大学医学部第 2 生理学教室 (主任 : 川上正澄教授)

佐久間康夫

\section{Effects of Limbic Stimulation and the Microiontophoresis of Aminergic Drugs on the Single Unit Activity of Hypothalamic Neurosecretory Cells}

\author{
Yasuo SAKUMA \\ Department of Physiology, Yokohama City University School of Medicine \\ Yokohama, Japan (Director : Prof. M. Kawakami)
}

\begin{abstract}
Attempts were made to investigate the chemical nature of hypothalamic afferents from the extrahypothalamic structures which participate in the control of hypothalamic neurosecretory cells. Experimental procedures were discribed in the preceding report, except that of the electrical stimulation and the microiontophoresis. Some part of data obtained in this study were referred in the preceding report for improvement of statistic reliability. For electrical stimulation, side-by-side bipolar electrodes were placed in the medial preoptic area (MPO), medial amygdala (mAMYG) and dorsal hippocampus (dHPC) from the parietal surface of the brain and fastened to the cranium by dental resin. Microiontophoresis of norepinephrine (NE), dopamine (DA) and acetylcholine (Ach) was carried out by using five-barrelled glass pipette on the antidromically activated units in the medial basal hypothalamus by the median eminence stimulation. Extracellular potentials were recorded by the central barrel of each electrode. One of the outer barrels was filled with physiological saline and used for control purpose.
\end{abstract}

(1) Electrical stimulation of the MPO with train pulses of $0.2 \mathrm{msec}$ duration and $300 \mu \mathrm{A}$ intensity in $100 \mathrm{~Hz}$ for $5 \mathrm{sec}$, induced facilitation and inhibition in $26.4 \%$ and $9.4 \%$ of 106 tests, respectively. By the mAMYG stimulation with $500 \mu \mathrm{A}$, facilitation was seen in $18.8 \%$ and inhibition in $10.4 \%$, of 96 tests. The HPC stimulation induced facilitation in $10.0 \%$ and inhibition in $23.3 \%$ of 90 tests.

(2) Facilitatory effect of the MPO was most frequently seen in the ovariectomized and estrogen primed rats $(58.8 \%$ of the tests). In contrast, the inhibitory effect of the dHPC was striking in the diestrus-I $(40.0 \%)$.

(3) Microiontophoresis of NE induced facilitation in $60.0 \%$ and inhibition in $10.6 \%$ 
of 66 identified cells. DA induced facilitation in $45 \%$, and inhibition in $11.7 \%$ of 60 tests. Ach induced facilitation in $41.4 \%$, and inhibition in $13.8 \%$ of 58 tests.

(4) By NE infusion, facilitation was most commonly seen in the proestrus $(70.6 \%)$. Inhibition was most readily elicited by Ach infusion on the diestrus-I (30\%). Facilitative effect of DA was eminent in the diestrus-I (81.8\%).

(5) Successive administration of NE and DA on identical units revealed that in $56.0 \%$, the units were responsive to only one agent and the other was effectless. $25.5 \%$ of the units responded to both of NE and DA.

(6) The coinceidence of effects, either facilitation or inhibition, between that of electrical stimulation and of the microiontophoresis, was calculated on 46 units. The facilitatory effect of the MPO was most commonly mimicked by NE infusion $(81.8 \%$ ), and the inhibitory effect of the dHPG by Ach infusion (46.7\%). NE also mimicked facilitatory effect of mAMYG stimulation $(73.3 \%)$.

(7) Intraventricular infusion of $20 \mu \mathrm{g}$ of NE induced significant increase of serum LH ( $\mathrm{p}<0.05$ to saline) when measured by radioimmunoassay, whereas DA resulted in a decrease of LH $(\mathrm{p}<0.01)$.

緒 言

視床下部神経分泌細胞から下垂体門脈に対して行われる放出ホルモン分泌の調節に関与する神経伝達分質 については, 各種の伝達遗断剂が排卵を阻止することを認めた Sawyer ら ${ }^{44), 46)}$ の先駆的報告以来, 多くの 研究がある. カテコールアミンの第 3 膇室内への投与が，適当な条件のもとで黄体形成ホルモン (LH) の 分泌を起てすととは Kamberi ら ${ }^{201}$ ，Schneider \& McCann ${ }^{48)}$ ，Karla ら ${ }^{19)}$ などによる一連の報告が行われて いるが，今日のところ，LH の放出を起とす生理的な伝達物質が具体的に何であるかについては結論が得ら れていない49.

LH の放出, あるいは非卵の誘発には, 脳内諸部位の電気刺激, 電気化学刺激が有効である. 視床下部正 中底部の刺激が排卵を誘発することは Harris 以来良く知られている事実であり ${ }^{177} ，$ この現象は視床下部正 中底部に局在する黄体形成ホルモン放出ホルモン (LH-RH) 分泌性の神経分泌細胞 11 ,45) が賦活された結果 と考えられる. 同時に LH-RH 活性が認められない(8) とされている内側視索前野 $(\mathrm{MPO})^{33,13,25)}$ や扁桃核 内側部 (mAMYG) ${ }^{53}$, 57) の電気刺激, 電気化学刺激によっても排卵が誘発されたり，LH の分泌が起こり， これに対し海馬（HPC）の刺激は自然排卵を抑制し ${ }^{56)}$ ，また MPO の刺激による LH 放出を阻止する ${ }^{299}$. これらの刺激効果が, 神経経路によって視床下部正中底部に伝達されているととは, 特定の神経経路の選択 的切断によって刺激が無勃となったり ${ }^{381}$ ，自然排卵が起こらなくなる観察 ${ }^{16), 301}$ ，あるいは脳内各部位の電気 刺激が視床下部正中底部の電気活動に及ぼす影響 ${ }^{28)}$ から明らかである.

視床下部神経分泌細胞に対するてれらの神経性入力機序が, その経路ごとに特異的な神経伝達物質によっ て興奮の伝達を行っている可能性については, 排卵誘発や LH 分泌を指標として, 脳内各部位の刺激を特異 的に遮断する薬剂から分析する試みが行われている6 ${ }^{61,12,422,577}$. しかしながら，乙れらの研究が必ずしも一 致した結論に達していないのは，指標とする排卵，あるいは LH 分泌が複䧴な生体機序の一部であって，遮 断剂が非特異的に作用してしまう可能性によるととが考学られる。

そこで本研究では, 視床下部正中底部に, 電気生理学的に同定した神経分泌細胞を対象として脳内諸部位 の電気刺激の効果と, ノルエピネフリン，ドーパミン仗びアセチルコリンの微小電気泳動投与の効果を, 同 
一の細胞で比較, 検剖し, 刺激部位から神経分泌細胞へ至る神経経路の化学的性質について考察した。さら に, 性周期や卵巣ホルモン投与などの体内内分泌環境の変化が, 電気刺激や微小電気泳動に対する細胞の反 応性に与える影響を観察し, 卵栄ホルモンのフィードバック調節に関与する経路についても検討を行った.

\section{実験材料及び方法}

実験動物及び基本的手技は既報第 I報 11 亿記載した。本実験では予め, 腹卧位で脳定位固定装置に動物を 装着し，MPO，mAMYG 及び HPC にステンレス線製並列双極電極を Albe-Fessard 弓22) の脳地図に従っ て頭頂部より刺入し，即時重合樹脂を用いて頭骨に固定したネジと接着した。しかるのち，動物を背臥位と し， 正中隆起 (ME) を腹側より露出し，神経分泌細胞の逆行性興奮誘発のための刺激電極を下垂体柄起始 部の $\mathrm{ME}$ 表面に置いた。記録及び薬物投与のための微小電極は，ME 表面から視床下部弓状核 (ARC) を 目標として視床下部正中底部に刺入した。

単一放電活動の記録及び薬物の微小電気泳動的投与には，5槽のガラス毛細管電極を使用した．電極は外 径 $3 \mathrm{~mm}$ パイレックスガラス管を菜材とし，川上 ${ }^{221}$ の方法により作成した. 電極先端の直径は $1 \mu$ 以内之 し，記録槽の直流抵抗は 15〜 50 Mohm，また，楽物投与槽の抵抗は $10 \mathrm{Mohm}$ 以上の屯のを用いた． 5 槽電 極の中心槽を記録槽とし，導出のために $0.5 \mathrm{M}$ 酶酸ナトリウム溶液を充填した。なお，溶液には pontamine sky blue 6B を $2 \%$ 濃度で混和し, 記録終了後の電極位置検索のため, 染色が可能になるようにした.

残る 4 槽には，それぞれ以下の溶液を充填した。 1M-Acetylcholine Chloride (Ach)，0.1M-Norepine phrine bitartrate (NE), 0.5M-Dopamine hydro chloride (DA), 0.15M-NaCl. 何れの溶液も $\mathrm{pH}$ は 3 〜 4 亿調整した. これらの溶液は Tasaki ら ${ }^{511}$ の方法により, 電極の使用直前に充填を行った。

薬物の投与は，逆行性興辜誘発によって，第I報に述べた神経分泌細胞と想定される特徴を示した細胞， 即ち誘発された波形に屈曲があり，A，B-スパイクの分離を示したあのについてのみ行ったななお，てれら の逆行性與奮の検討は第 I 報で記載した. 投与は Curtis ${ }^{10)}$, Moss $ら^{371}$ の方法に從い, 電気泳動的に行った. 微小電極からの薬物の駆出には，何れも正の電流を用い，5 40 nA，5秒間の通電により単一放電活動に 変化を認めた。 $0.15 \mathrm{M}-\mathrm{NaCl}$ 槽の通電に対する反応を対照とし，さらに薬物の效果の判定には Curtis \& Koizumi ${ }^{111}$ の基準を参考にした．本実験では投与による単一放電活動の変化が対照の40\%以上の增加，又は 減少を示した時を有意な反応と考えた。

記録終了後 $10 \mu \mathrm{A}$ の負電流を記録槽に10分間通電し，電極先端より染色剂を遊出させた. 10\%ホルマリ ンの心臟灌流ののち，脳を固定し，60 切片を作成，染色後記録部位の同定を行った.

第 5 節で述べた性腺刺激ホルモンの定量法は Niswender ら ${ }^{391}$ の方法に従いラジオイムノアッセイ法によ って行った.

本文中では以下の略号を用いた。 Pe : 自然性周期発情前期；DI：自然性周期非発情第 1 日；Ovx：卵巣 摘出無処置; $\mathrm{Ovx}+\mathrm{E}:$ 卵巣摘出後エストロジェン処置; $\mathrm{Ovx}+\mathrm{P}:$ 秡巣摘出後プロゲステロン処置.

\section{結果}

\section{1. 脳内諸部位の電気刺激が視床下部正中底部神経分泌細胞に及ぼす効果について}

脳内 MPO, mAMYG 及び HPC に刺入したステンレス線並列双極刺激電極の $0.15 \mathrm{M}-\mathrm{NaCl}$ 溶液中で の初期抵抗は 30-70 kohm であった. この電極を通じてパルス幅 $0.2 \mathrm{msec}$ の陰性矩形波を, $100 \mathrm{~Hz}$ の絽 り返し頻度で 5 秒間投与した. 刺激の強度は MPO では $300 \mu \mathrm{A}, \mathrm{mAMYG}$ では $500 \mu \mathrm{A}, \mathrm{HPC}$ では 100 $\mu \mathrm{A}$ とした. これらの刺激強度では，種々の内分泌環境を通じ，前頭葉皮質から記録した脳波に発作波を誘 発することがないことを確めた。いろい万の内分泌環境下で MPO 刺激に対してはのべ106例, mAMYG で は96例, HPC では 90 例の, それぞれ逆行性與奮の誘発により同定された視床下部正中底部の神経分泌細胞 の反応を観察した（Table 1).

種々の内分泌環境下に於ける観察を合計すると，MPO の刺激によって，26.4\%（28例）に刺激中及び刺 
Table 1. Responses of antidromically identified ARC units to the electrical stimulation of the MPO, m-AMYG and d-HPC under various endocrine conditions.

\begin{tabular}{|c|c|c|c|c|c|c|c|}
\hline \multicolumn{3}{|c|}{ Total } & \multirow{2}{*}{$\frac{\text { Proestrus }}{8(40.0 \%)}$} & \multirow{2}{*}{$\frac{\text { Diestrus } I}{5(19.2 \%)}$} & \multirow{2}{*}{$\frac{\text { Ovx. }}{2(10.0 \%)}$} & \multirow{2}{*}{$\frac{\mathrm{Ovx} .+\mathrm{EE}}{10(58.8 \%)}$} & \multirow{2}{*}{$\frac{\text { Ovx. }+\mathrm{P}}{3(13.0 \%)}$} \\
\hline MPO & 106 & $\uparrow 28(26.4 \%)$ & & & & & \\
\hline & & $\downarrow 10(9.4 \%)$ & $5(25.0 \%)$ & $2(7.7 \%)$ & 0 & $2(11.8 \%)$ & $1(4.3 \%)$ \\
\hline & & $\pm 68(64.2 \%)$ & $7(35.0 \%)$ & $19(73.1 \%)$ & $18(90.0 \%)$ & $5(29.4 \%)$ & $19(82.6 \%)$ \\
\hline \multirow{3}{*}{\multicolumn{2}{|c|}{ m-AMYG 96}} & $\uparrow 18(18.8 \%)$ & $9(47.4 \%)$ & $2(8.3 \%)$ & $1(5.6 \%)$ & $5(33.3 \%)$ & $1(5.0 \%)$ \\
\hline & & $\uparrow 10(10.4 \%)$ & $4(21.1 \%)$ & $1(4.2 \%)$ & $2(11.1 \%)$ & $2(13.3 \%)$ & $1(5.0 \%)$ \\
\hline & & $\pm 68(70.8 \%)$ & $6(31.6 \%)$ & $21(87.5 \%)$ & $15(83.3 \%)$ & $8(53.3 \%)$ & $18(90.0 \%)$ \\
\hline \multirow[t]{3}{*}{ d-HPC } & 90 & $\uparrow 9(10.0 \%)$ & $3(17.6 \%)$ & $1(10.0 \%)$ & $2(11.1 \%)$ & $2(13.3 \%)$ & $1(5.0 \%)$ \\
\hline & & $\uparrow 21(23.3 \%)$ & $4(23.5 \%)$ & $4(40.0 \%)$ & $3(16.7 \%)$ & $5(33.3 \%)$ & $5(25.0 \%)$ \\
\hline & & $\pm 60(66.7 \%)$ & $10(58.8 \%)$ & $5(50.0 \%)$ & $13(72.2 \%)$ & $8(53.3 \%)$ & $14(70.0 \%)$ \\
\hline
\end{tabular}

$\uparrow:$ increased $\quad \downarrow$ : decreased $\%:$ no change

激終了後も持続する放電頻度の増加を認めた.9.4\% (10例) では刺激により放電が抑制された・mAMYG の刺激では $18.8 \%$ (18例) において促進，10.4\% (10例) で抑制をみた.とのように，MPOと mAYGの 刺激に対しては，促進性の反応が相対的に優勢であったのに対し，HPC 刺激に対しては促進性反応の 10.0 $\%$ ( 9 例) に対し, 抑制性反応の $23.3 \%$ (21例) と, 抑制性反応の方が 2 倍の頻度で認められた.

内分泌環境の变化に伴って, 刺激の効果には種々の変動が認められた. MPO 刺激による促進反応の惹起 は Ovx +E (17例中10例； 58.8\%) 及び Pe (20例中 8例；40\%) で特に顕著であった。抑制反応にあ，や や共通の傾向が認められた. mAMYG 刺激による促進反応は $\mathrm{Pe}$ で最も著しく（19例中 9 例； 47.4\%), Ovx $+\mathrm{E}$ がこれに次いだ (15例中 5 例 ; 33.3\%). 抑制反応は Pe，Ovx，Ovx+E で相対的に高率を示し た. HPC 刺激が相対的に高い頻度で促進反応を起こしたのは Pe であったが，その比率は高くなかった (17例中 3 例；17.6\%). 乙れに対し，HPC 刺激による抑制性の反応は，特に DI (10例中 4 例；40\%) 仡 び Ovx +E (15例中 5 例 ; 33.3\%) で高率をしめた.

この結果から, MPO から視床下部正中底部の神経分泌細胞に至る促進性経路の興舊性は, Pe 及び Ovx $+\mathrm{E}$ において上昇しているものと思われる．MPO 刺激に対する抑制性反応の比率む $\mathrm{Pe}$ 及び Ovx+E で増加 していることから見て，乙れらの内分泌環境における與舊性の上昇が，一定の程度刺激部位である MPOの 興奮閾值の低下によっている可能性が考えられるが，同時に視床下部正中底部に至る興奮伝達機序に内分泌 環境が作用しているととあ無視できない. mAMYG の刺激では, MPO と同様 Pe と Ovx+Eで促進性の 反応の頻度が高かったが, HPC からの系に関しては, 特に抑制性機能が DI で賦活されている所見を得た. 何れの部位の刺激についてす, MPO 刺激と同様に, 内分泌環境の变化が系のどの段階で作用しているかは 明らかでない. 視床下部神経分泌細胞の膜の段階での感受性が, 内分泌環境によって受ける変化については 以下の実験で調べた.

\section{2. 微小電気泳動法による薬物投与が神経分泌細胞の活動に及ぼす効果について}

ME からの逆行性與奮誘発によって同定した神経分泌細胞に対し，NE，DA 及び Ach の微小電気泳動的 投与を行い, 単一放電活動に及ぼす効果を観察した（Table 2). 薬物の投与に先立って，何れの場合も $\mathrm{NaCl}$ 槽からの通電を行い，細胞の活動に变化が起こらないことを確かめた. 電気泳動的投与は 0 ～ $40 \mathrm{nA} ， 5$ 秒 間の通電によって行い，保持用電流は加えなかった. 投与は 2 分間の間隔をおいて, 段階的に強度を增加し て行った. 何れの薬物についても, 投与に用いた電流の大きさと反応の間に相関関係が認められた. NE 投 与による促進反応の dose-respones 関係の一例を Fig. 1 に示した. 一般に反応は通電開始後 $0.5 \sim 1.0$ 秒 
Table 2. Responses of identified ARC units to the microiontophoresis of NE, DA and Ach.

\begin{tabular}{|c|c|c|c|c|c|c|c|c|c|c|c|c|c|c|}
\hline & & & \multicolumn{4}{|c|}{$\mathrm{NE}$} & \multicolumn{4}{|c|}{ DA } & \multicolumn{4}{|c|}{ Ach } \\
\hline & & & $\uparrow 40$ & $\downarrow 7$ & \pm 19 & - & $\uparrow 27$ & $\downarrow 7$ & \pm 26 & $6 * * *$ & $\uparrow 24$ & $\downarrow 8$ & \pm 26 & $8^{*}\left(2^{* *}\right)$ \\
\hline \multirow[t]{4}{*}{$\mathrm{NE}$} & 66 & $\uparrow 40$ & - & - & 一 & - & 12 & 2 & 21 & 5 & 17 & 4 & 16 & 5 \\
\hline & & $\downarrow 7$ & - & - & - & - & 2 & 3 & 1 & 1 & 3 & 1 & 0 & 1 \\
\hline & & \pm 19 & - & - & - & - & 13 & 2 & 4 & 0 & 4 & 3 & 10 & 2 \\
\hline & & - & - & - & - & - & - & - & - & - & - & - & - & - \\
\hline \multirow[t]{4}{*}{ DA } & 60 & $\uparrow 27$ & 12 & 2 & 13 & - & - & - & - & - & 12 & 5 & 8 & 2 \\
\hline & & $\downarrow 7$ & 2 & 3 & 2 & - & - & - & - & 一 & 5 & 0 & 2 & 0 \\
\hline & & \pm 26 & 21 & 1 & 4 & - & - & - & - & - & 7 & 3 & 16 & 0 \\
\hline & & $6 * * *$ & 5 & 1 & 0 & - & - & - & - & - & - & - & - & - \\
\hline \multirow[t]{4}{*}{ Ach } & 58 & $\uparrow 24$ & 17 & 3 & 4 & - & 12 & 5 & 7 & - & - & - & - & - \\
\hline & & $\downarrow 8$ & 4 & 1 & 3 & - & 5 & 0 & 3 & - & - & - & - & - \\
\hline & & \pm 26 & 16 & 0 & 10 & - & 8 & 2 & 16 & - & - & - & - & - \\
\hline & & $8 *(2 * *)$ & 5 & 1 & 2 & - & 2 & 0 & 0 & - & - & - & - & - \\
\hline
\end{tabular}

$\uparrow:$ increased $\quad \downarrow$ : decreased $\quad \pm$ : no change

$*$ : not tested with NE ** : not tested with DA $* * *$ : not tested with NE

\section{Ovx.+Estrogen.}

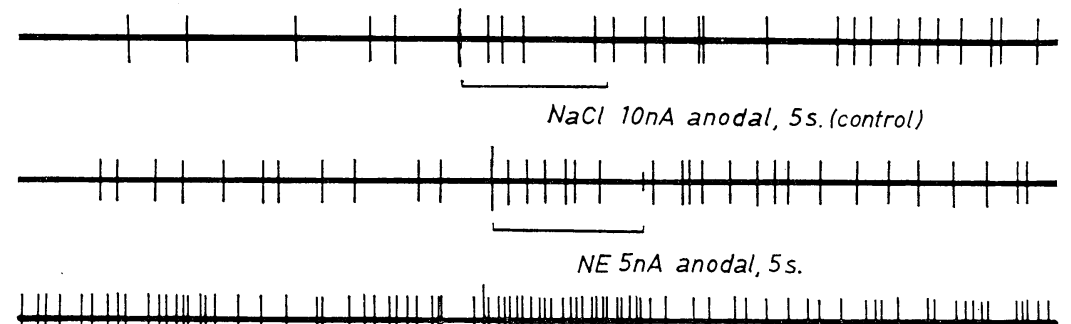
HUH

NE $6 \cap A$.

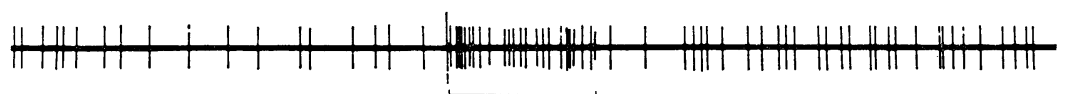

NE 7.5nA.

Fig. 1. An example of the relation of dose-response of an antidromically identified arcuate (ARC) neuron to the microiontophoresis of norepinephrine (NE).

の潜時で発現し, 通電終了後数秒から十数秒の後効果を伴うものが多かった (Fig. 2). 継時的に行った NE, DA, Ach の投与が，それぞれ異った反応を惹起した観察は， $\mathrm{NaCl}$ 槽からの電流投与の効果を参照すると， 微小電気泳動の効果が電流によるのではなく, 投与された薬物の作用であることを示している。

$\mathrm{NE}$ の投与は, 種々の内分泌環境下の動物で, のべ66の同定された神経分泌細胞に対して行い, 40 例(60.6 \%) で放電活動の促進を認めた. 19例（28.8\%）は無反応で，7例 (10.6\%) で抑制が起こった.60例につ いては更に DA の効果を調べた. DA は27例 (45.0\%) で促進反応， 7 例 $(11.7 \%$ ) で抑制反応を起とし た. 残る26例 (43.3\%) では無効であった. これらの細胞のうち, 58例については引き続いて Ach の投与 を行い，24例 (41.4\%) で促進，8例 (13.8\%) で抑制を観察した. 残る26例 (44.8\%) は Ach に対して 
PROESTRUS

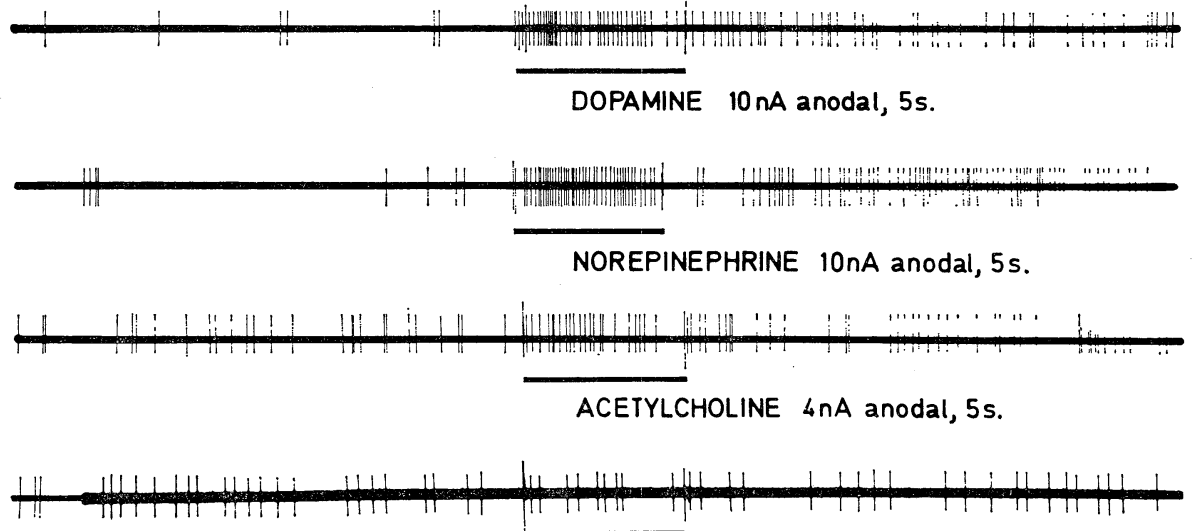

$\mathrm{NaCl} 10 \mathrm{nA}$ anodal, 5s. (control).

Fig. 2. Variable responses of an identical ARC neuron to the microiontophoresis of dopamine (DA), NE and acetylcholine (Ach).

反応を示さなかった。

同一の細胞に対して NE，DA，Ach を継時的 に投与した場合の，それぞれの薬物に対する反応 態度の関連を調べた. NE と DA の双方を投与し た60例のうち，促進及び抑制の何れを問わず，両 者に対して反応を示したものは19例 $(31.7 \%)$ あ った．乙れに対し NE のみに反応し DA には反 応を示さなかった細胞は22例 (36.7\%)，逆にDA のみに反応した細胞は15例 (25.0\%) 観察された. 4 例は NE，DA の何れにあ反応しなかった。即 ち, NEと DA については, 共通の反応性を示す 細胞は NEだけに反応する細胞より低い割合を示 した.とれに対し NEとAch に対する反応で は，総数58例のうち 25 例 $(41.7 \%)$ が，DA と Ach に対する反応では総数58例のうち22例 (37.9\%) が，それぞれ投与した薬物の双方に反応し，一方 の薬物のみに反応する細胞よりも，てれら共通の 反応性を有する細胞の方が何れも高い割合をしめ た (Fig. 3).

これらの観察から, 本実験で投与した 3 種の薬 物の中では, 視床下部神経分泌細胞の活動に最む 影響を与えるのは NE であり，てれと比較すれ ば反応性のある細胞の比率は小さいが DA 及び Ach についても過半数が反応性を示すととが確認 された. てれらの反応のうち, NEによるあのは, 促進性反応と抑制性反応の比率が 6 対 1 と, 促進 性反応の頻度が圧倒的であったのに対し，Achに

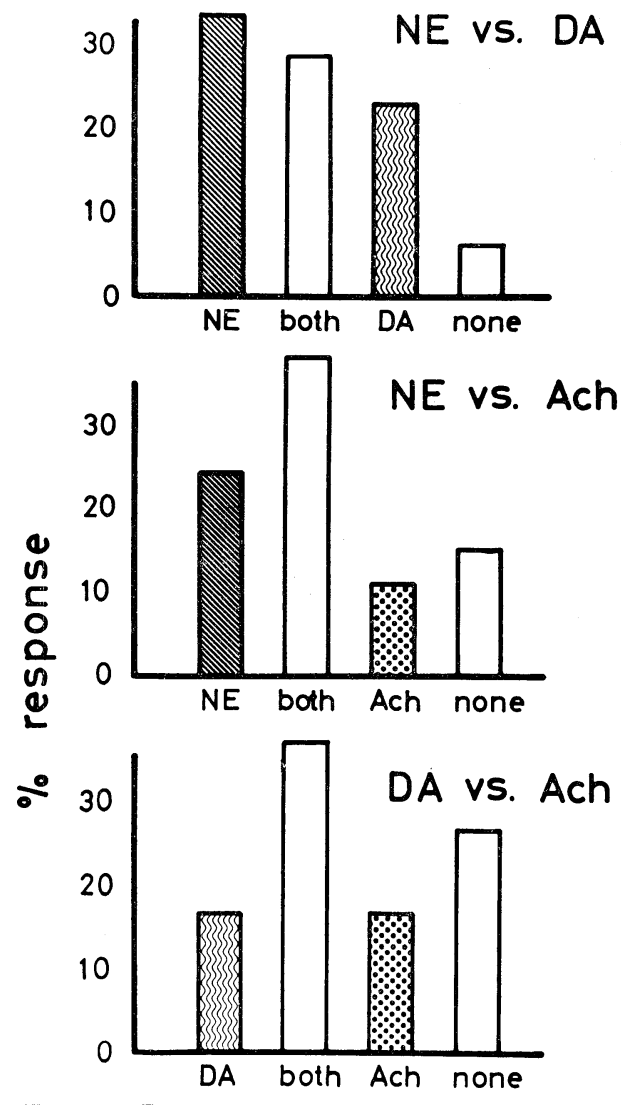

Fig. 3. Relationship between the responses elicited by two drugs out of DA, NE and Ach in the antidromically identified ARC neurons. 
対する反応では 3 対 1 で, 比較的抑制性反応の頻度が高かった。 DA 投与に対するての比率はほぼ 4 対 1 で あった. 単一の細胞に対する複数の薬物の投与の效果から考えると, 視床下部正中底部においては NEに反 応する系と, DA に反応する系の 2 系列があり, Ach はこの双方に有効であるととが想定された.

\section{3. 内分泌環境の変動に伴って神経分泌細胞にみられる薬物反応性の変化について}

動物の自然性周期及び各種の内分泌学的処置に伴って起こる視床下部正中底部神経分泌細胞の反応性の変 化を Table 3 に示す.

Table 3. Changes of the responsiveness of the antidromically identified ARC units to the microiontophoresis according to the endocrinological variations.

\begin{tabular}{ccc|c|c|c|c|c}
\hline \multicolumn{2}{c}{ Total } & & Proestrus & Diestrus I & Ovx & Ovx $+\mathrm{E}$ & Ovx +P \\
\hline \hline NE & 66 & $\uparrow 40(60.6)$ & $12(70.6)$ & $7(58.3)$ & $7(63.6)$ & $8(53.3)$ & $6(54.5)$ \\
& & $\downarrow 7(10.6)$ & $1(5.9)$ & $2(16.7)$ & $1(9.1)$ & $1(6.7)$ & $2(18.2)$ \\
& & $\pm 19(28.8)$ & $4(23.5)$ & $3(25.0)$ & $3(27.3)$ & $6(40.0)$ & $3(27.3)$ \\
& & & & & & \\
DA & \multirow{2}{*}{60} & $\uparrow 27(45.0)$ & $7(50.0)$ & $9(81.8)$ & $3(27.3)$ & $6(46.2)$ & $2(18.2)$ \\
& & $\downarrow 7(11.7)$ & 0 & 0 & $4(36.4)$ & $2(15.4)$ & $1(9.1)$ \\
& & $\pm 26(43.3)$ & $7(50.0)$ & $2(18.2)$ & $4(36.4)$ & $5(38.5)$ & $8(72.7)$ \\
& & & & & & \\
Ach & 58 & $\uparrow 24(41.4)$ & $11(78.6)$ & $4(40.0)$ & $3(27.3)$ & $2(18.2)$ & $4(33.3)$ \\
& & $\downarrow 8(13.8)$ & $1(7.1)$ & $3(30.0)$ & $1(9.1)$ & $3(27.3)$ & 0 \\
& & $\pm 26(44.8)$ & $2(14.3)$ & $3(30.0)$ & $7(63.6)$ & $6(54.5)$ & $8(66.6)$ \\
\hline
\end{tabular}

$\mathrm{NE}$ 亿対する反応性はOvx+E を除く内分泌環境下にあっては，ほぼ75\%の細胞が促進，抑制何れかの 反応を示した. Ovx +E では反応は $60 \%$ の細胞に見られた。これらの反応のうち, 促進が目立って多かった のは $\mathrm{Pe}$ で 17 例中 12 例 $(70.6 \%)$ が NE の投与に対して放電頻度の增加を起とした・ NE に対する抑制性 の反応は DI (12例中 2 例 $; 16.7 \%)$ 及び Ovx $+\mathrm{P}$ (11例中 2 例 $; 18.2 \%$ )で相対的に多く, Pe (17例中 1 例； $5.9 \%)$ 及び $\mathrm{Ovx}+\mathrm{E}(15$ 例中 I例； $6.7 \%)$ で少なかった.

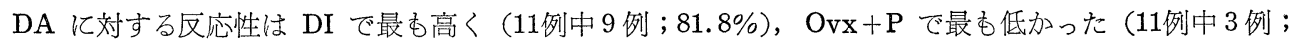
$27.3 \%)$. このうち抑制性の反応は, 卵巣摘出及びホルモン処置を行った群のみに見られ，Ovx で最も高い 比率を示した (11例中 4 例; $36.4 \%)$.

Ach に対する反応性は Pe で最む高く14例中 12 例 (85.7\%) が促進及び抑制反応を示した. Ach に対す る促進反応は $\mathrm{Pe}$ で高率を示した（14例中11例； 78.6\%). これに対し抑制反応の比率は DI で最も高かっ た（10例中 3 例； $30.0 \%)$.

内分泌環境に伴う神経分泌細胞の薬物反応性の变化の機序については, 細胞の膜自体の感受性の変化によ る可能性だけでなく，投与した薬物と同一，あるいは近似の作用をすつ物質を神経伝達物質とする系が特定 の内分泌環境下で賦活, 抑制されているために, 神経分泌細胞の興舊状態に変化を与えるために必要な薬物 の量が異なってくるとも考えられる.

\section{4. 脳内諸部位の刺激効果亡薬物の微小電気泳動的投与の効果の関係について}

のべ46の同定された神経分泌細胞については, 脳内諸部位の電気刺激の効果及び薬物の微小電気泳動的投 与の効果を継時的に観察した (Table 4). 表に見られるように MPO 刺激によって活動の促進を示した 22 例のうち, 18 例 $(81.8 \%)$ は NE の投与により同様な促進反応を起とした. DA の投与は 22 例の細胞の過 半数 (14例； 63.6\%) で無効で，6例 $(27.8 \%)$ 飞促進反応を起としたにとどまった. MPO 刺激が促進を 起とした細胞のうち，14例については，Ach の投与む行ったが，それぞれ6例 (42.8\%) が促進反応と無反 
Table 4. Correlation of effects on the identified ARC units between the electrical stimulation and the microiontophoresis.

\begin{tabular}{|c|c|c|c|c|c|c|c|c|c|c|c|}
\hline & & & \multicolumn{3}{|c|}{$\mathrm{NE}$} & \multicolumn{3}{|c|}{$\mathrm{DA}$} & \multicolumn{3}{|c|}{$\mathrm{AcH}$} \\
\hline & & & $\uparrow$ & $\downarrow$ & \pm & $\uparrow$ & $\downarrow$ & \pm & $\uparrow$ & $\downarrow$ & \pm \\
\hline \multirow[t]{3}{*}{ MPO } & 46 & $\uparrow 22$ & 18 & 2 & 2 & 6 & 2 & 14 & 6 & 2 & 6 \\
\hline & & $\downarrow 6$ & 4 & 1 & 1 & 3 & 1 & 2 & 2 & 2 & 2 \\
\hline & & \pm 18 & 8 & 3 & 7 & 9 & 1 & 8 & 10 & 4 & 4 \\
\hline \multirow[t]{3}{*}{$\mathrm{m}-\mathrm{AMYG}$} & 45 & $\uparrow 15$ & 11 & 0 & 4 & 3 & 2 & 10 & 8 & 0 & 7 \\
\hline & & $\downarrow 10$ & 8 & 1 & 1 & 3 & 2 & 3 & 1 & 5 & 2 \\
\hline & & \pm 20 & 12 & 3 & 5 & 13 & 1 & 6 & 9 & 3 & 3 \\
\hline \multirow[t]{3}{*}{$\mathrm{d}-\mathrm{HPC}$} & 43 & $\uparrow 5$ & 4 & 0 & 1 & 4 & 0 & 1 & 2 & 0 & 2 \\
\hline & & $\downarrow 15$ & 8 & 3 & 4 & 3 & 1 & 11 & 0 & 7 & 1 \\
\hline & & \pm 23 & 16 & 1 & 6 & 12 & 3 & 6 & 11 & 1 & 9 \\
\hline
\end{tabular}

応をしめた．MPO 刺激に対する抑制反応之，薬物投与の効果の間には特に相関は認められなかった。 $\mathrm{mAYG}$ 刺激については，電気刺激が促進反応を起こした15例のうち，NE は 11例 $(73.3 \%)$ に促進反応 を起とした.Ach は8例 (53.3\%) を促進した. これに対し DA は大多数 (10例；66.7\%) で無効で, 僅 が 3 例 $(20.0 \%)$ で促進を起としたにとどまった. HPC 刺激により促進反応を示した 5 例では, NE, DA の投与に対しても促進反応を示すのが認められた．HPC 刺激に対しては，15例 (34.8\%) で抑制反応を認 めた。これらの細胞では 8 例 (53.3\%) が NE に対して促進反応, DA に対しては11例 (73.3\%) までが 無反応であった. Ach を投与した 8 例中 7 例 $(87.5 \%)$ が HPC 電気刺激と同じく抑制効果を示した.

この結果から, 脳内諸部位に発して視床下部正中底部神経分泌細胞に至る, 促進性及び抑制性の神経経路 の化学的性質を推論すると，MPO からの系は主として促進性であって，乙の系の効果は NE の微小電気泳 動的投与により，模做された． mAMYG よりの系とついては促進性がやや優勢ではあったものの，㧕制性 反応もかなり観察され，乙のうち促進性反応の観察された細胞では NE 及び Ach の双方によって電気刺激 の効果が模做された. MAMYG からの抑制性影響についてむAch が同様の効果を示した. HPC からの促 進性入力は，NE 及び DA によって同様の効果を得ることができた．HPC 刺激に対して抑制反応を示した 細胞は，Ach の微小電気泳動投与によって同様に抑制反応を示すむのが大多数であったととから，との抑制 系が Ach 作動性である可能性が考えられる. この抑制機序に対し，NE 作動性の拮抗的促進機序が存在す るととが，HPC 及び mAMYG の刺激により抑制をうける細胞の大多数が NE の投与で逆に促進を受ける ととから想定された。

\section{5. 薬物の第 $\mathbf{3}$ 脳室内への投与が血獎中の性腺刺激ホルモンに及ぼす影響について}

発情前期の午後, 13 時 30 分にペントバルビタール $-\mathrm{Na}$ 塩 $\left(\right.$ Nembutal $\left.^{\mathrm{R}}\right)$ を $31.5 \mathrm{mg} / \mathrm{kg}$ 投与して $\mathrm{LH} の$ 放出をブロックした動物において，第 3 脳室に定位的に刺入した先端 $100 \mu$ のガラス製カニューレを通じ て，それぞれ $20 \mu \mathrm{g} の \mathrm{NE}, \mathrm{DA}$ 及び epinephrine bitartrate (EP) を何れも $10 \mu 1$ の溶液として投与し た. 対照には $0.15 \mathrm{M} \mathrm{NaCl}$ を投与し, sham operated group には開頭し，カニューレを刺入し，直ちに 抜去した動物を用いた。採血は投与後30分で行った。

$\mathrm{NE}$ の投与により, 血獎中 $\mathrm{LH}$ 濃度には, $\mathrm{NaCl}$ を投与した動物に対して有意 $(\mathbf{p}<0.05)$ の増加が認め られた (Fig. 4-8). これに対し, 同量の DA の投与は LH の著しい $(\mathrm{p}<0.01)$ 滅少を起とした. 卵胞 刺激ホルモン (FSH) の血中濃度は NE の脳室内投与で著しい（p<0.01）低下を示した。DA による FSH の減少は統計学的には有意でなかった。 


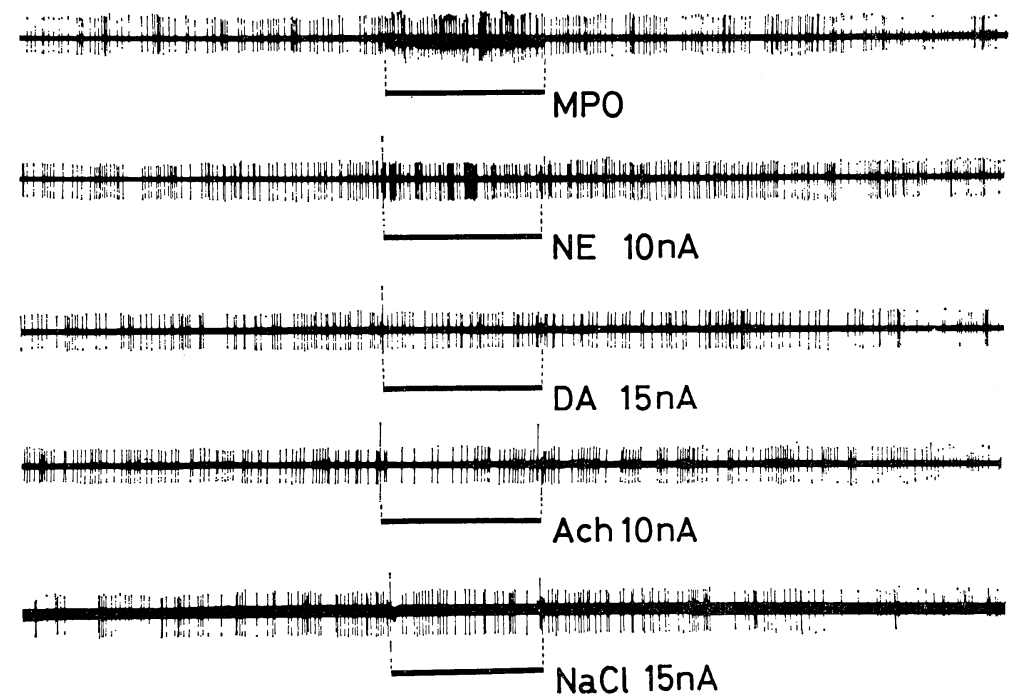

Fig. 4. Example of responses of an antidromically activated ARC neuron to the medial preoptic (MPO) stimulation and the microiontophoresis.
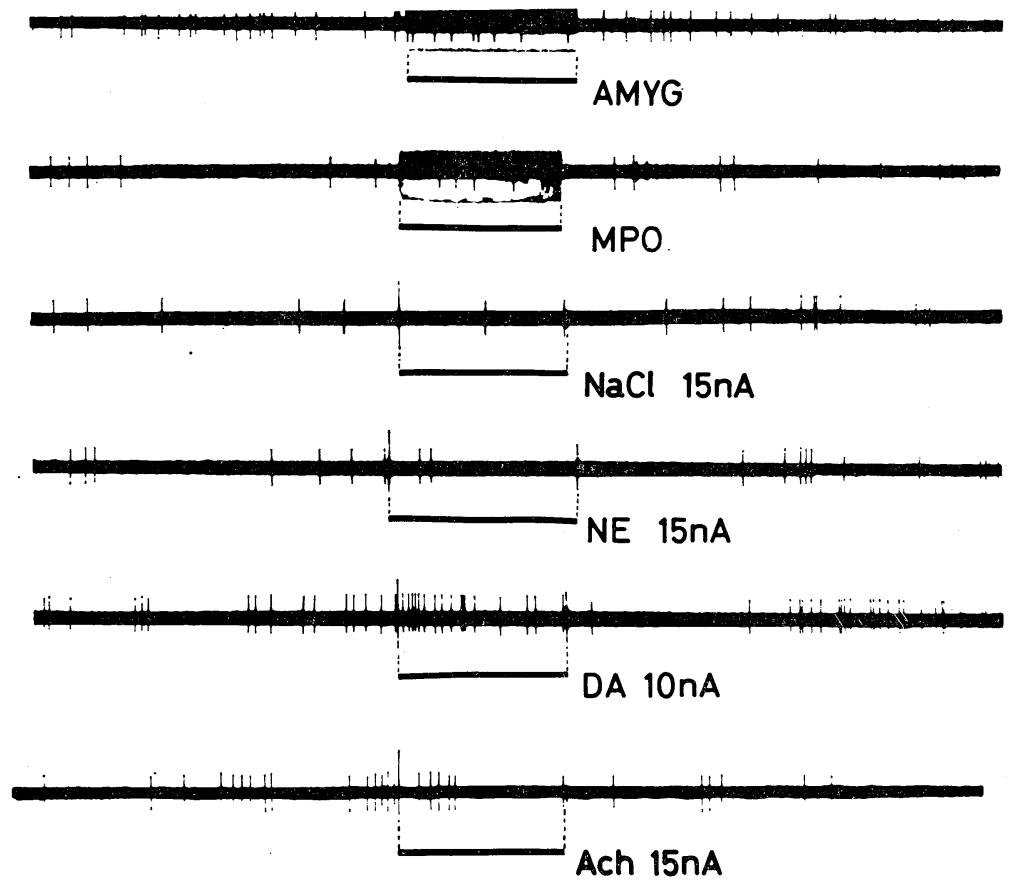

Fig. 5. Responses of an antidromically activated ARC neuron to medial amygdalar (AMYG) stimulation and the microiontophoresis. 

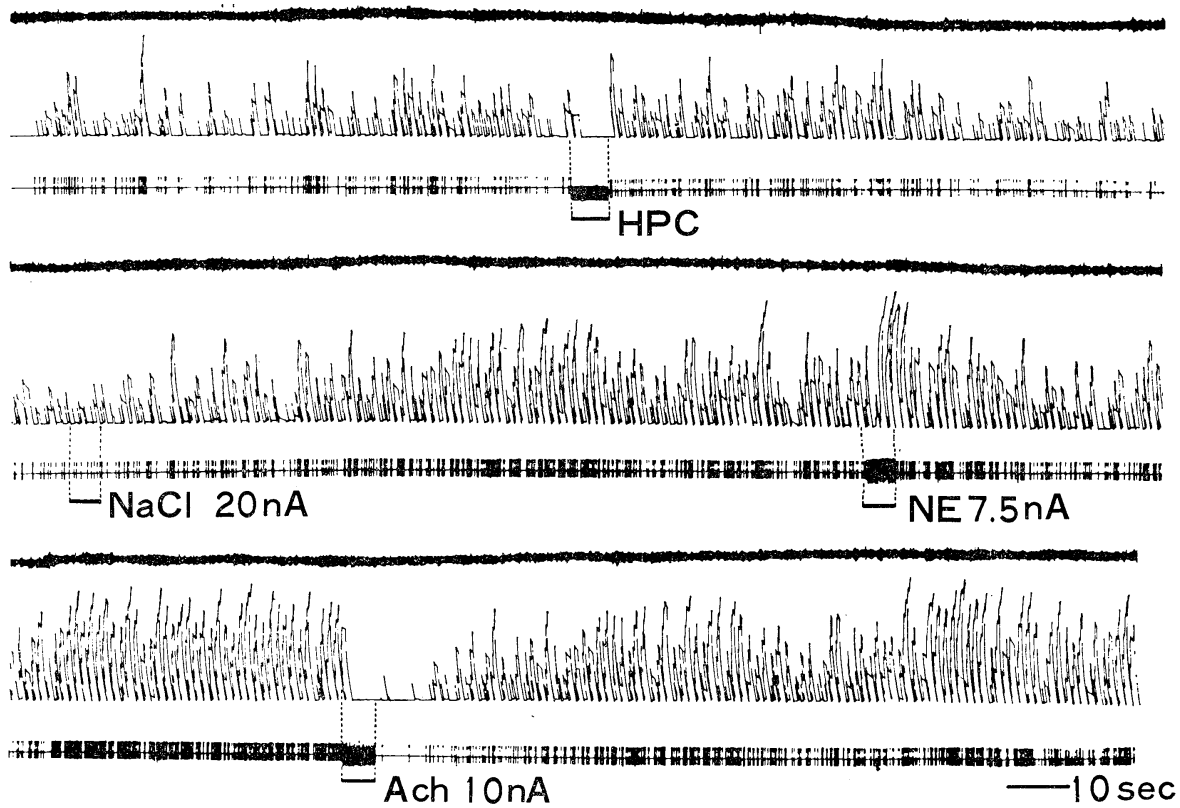

Fig. 6. Inhibitory effects of the hippocampal (HPC) stimulation and the microiontophoresis of Ach on the activity of an identified ARC neuron. Upper column of each traces : cortical EEG; Middle column : integrated unit activity.
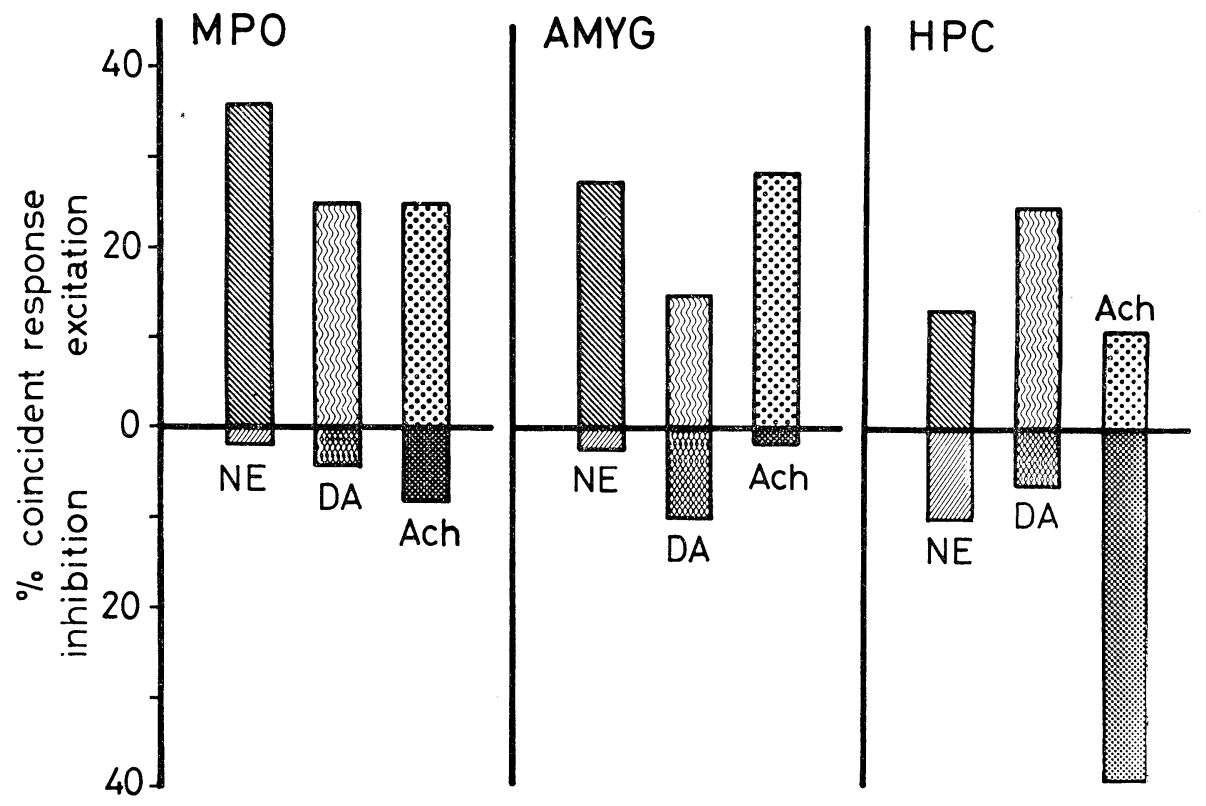

Fig. 7. Relationship between the effects of electrical stimulation and the microiontophoresis. 


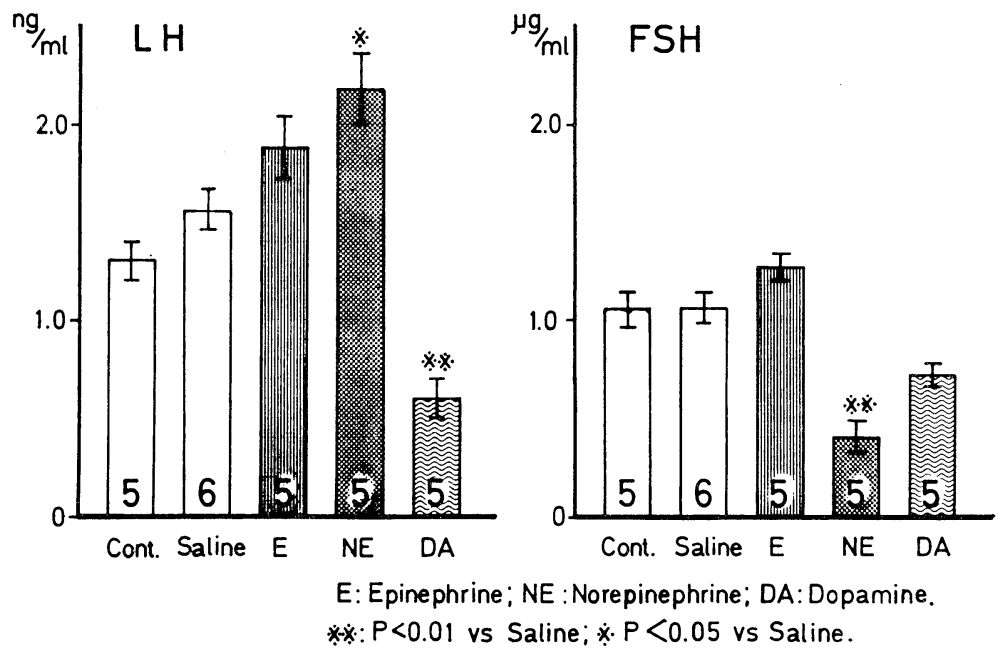

Fig. 8. Effects of intraventricular infusions of catecholamines on serum $\mathrm{LH}$ and FSH.

考察

本実験では視床下部正中底部の神経分泌細胞に対する膇内諸部位からの神経性大力とその化学的性質につ いて検討至行った。

排卵の生理的過程に MPO と視床下部正中底部の間を結ぶ神経路が不可欠であるととは, 広く認められて いる ${ }^{16), 322,52)}$. 本実験で検索の対象とした ME 亿軸索を直接送っている神経分泌細胞のうち，4 分の 1 以上 が MPO の電気刺激によって促進反応を示した．との促進反応は MPO の電気刺激, 電気化学刺激が, 下

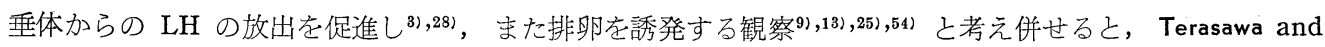
Sawyer ${ }^{54)}$ や Kawakami ら ${ }^{27)}$ の述へているように LH の放出之直接関連する現象の可能性がある. MPO の 刺激剂果が神経路を介して, 視床下部正中底部に至り, そこで興釜を放出因子分泌性の神経分泌細咆に伝達 した結果現われていることは，化学的にシナプス伝達を遮断すると考えられている物質の投与により排卵が 阻止されることから推論される. Sawyer ら ${ }^{46)}$ は古く交尾直後のウサギにアトロピンやダイベナミンを投与.

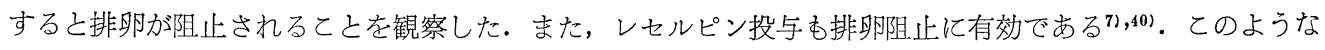
処置を行った動物です，MPO の刺激により排卵の誘発40)，LH の放出を起とすてとが知られているが，乙

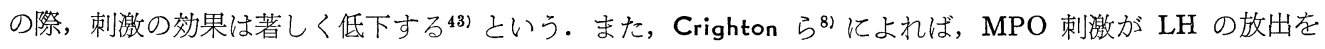
起乙すが, MPO 自体には LH-RH 活性は認められないという。これらの観察は何れす視床下部正中底部の 神経分泌細胞に対し, 神経性の大力が, 神経伝達物質を介して調節を行っているととを示㕹している.

一方, 本実験で試みた薬物の微小電気泳動的投与によって, 視床下部正中底部の神経分泌細胞に, 最も著 明な活動の促進を起てしたのは NE であった. カテコールアミン類が LH-RH の分泌調節に関与している てとは, 今日広く認めら机いるとてろであるが, 実際に, どの化合物が, どのような形式で LH-RH 調 節を行っているかについては結論が得られていない. 組織化学的研究により, 視床下部正中底部には DA が

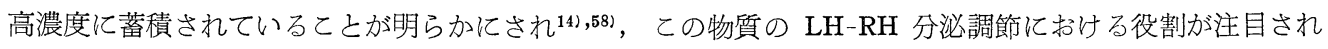
て多くの研究が行われた. Fuxe ら ${ }^{1118)}$ は一連の系統的研究により, ME の DA 末端が LH-RH の放出を 抑制すると述べている(18). これに対し McCann ら ${ }^{36), 48)}$ ，Kamberi ${ }^{203}$ は DA が LH-RH 放出を起てす神 経伝達物質であると考えている. 本実験の結果は DA の微小電気泳動的投与が $45 \%$ の神経分泌細胞に活動 の促進を起こしたが，乙れらの細胞の多くは MPO 刺激には反応していない，また，第 3 脳室内への DA 投与によっても， LH の分泌抑制が起こっており，本実験の結果から DA は神経分泌細胞の活動を調節す 
る促進性伝達物質として作用しているとは考え難い，DA に関しては, 我々はむしろ ME におけるシナプ ス前抑制様機序による LH-RH 分泌抑制機序への関与を想定している ${ }^{23,4111}$.

本実験の結果から推論すると, 神経分泌細胞に対する促進性神経伝達物質として最も考え易いのはNEで ある. NE は 60.6\%の細胞の活動を促進し，しかもてれらの細胞の殆んどが MPO 刺激によっても促進反 応を示している. NE (又は EP) が LH 放出を促進するという観察は古くは Markee ら ${ }^{35)}$ が下垂体前莱に 投与し，おそらくは拡散による ARC-ME への到達の結果排卵の誘発に成功した報告がある．Kalra ら ${ }^{191}$ は去勢ラットにプロゲステロンを投与して起とる LH 分泌に NE が関与すると述べておりままた最近 Sawyer ら ${ }^{45)}$ はウサギで NE が LH の放出を起とすのに対し，DA は逆に抑制を起とすととを認め，しか あ DA は長期間にわたって NE 投与に対する LH 分泌反応を阻止すると述べている．また，Tima and Flerko55) は持続照明や MPO-視床下部正中底部神経路の切断によって, 持続発情状態となったラットの第 3 脳室に NE を投与し，排卵を誘発するととに成功しており，乙れらの報告は，本実験の結果と基本的に 一致していると考えられる.

微小電気泳動的投与による NE の投与の際, 動物の内分泌環境による反応性の差が認められた。乙の変化 が神経分泌細胞付対する卵巣ホルモン，あるいは下垂体前葉ホルモン等の直接のフィードバック作用の結果 であるのか，あるいは内分泌環境に伴って，MPO から神経分泌細胞へ至る系の活動水準が変化し，その結 果 NE 投与に対する閾值が低下していることによるのかは，本実験の限りでは明瞭でなく，乙の両者の可能 性とあ否定できないように思わ机る，視床下部正中底部に存在するカテコールアミンの量が性周期あるいは 内分泌環境化伴って変動を示し, Pe 又は Ovx $+\mathrm{E}$ で相対的に高い值を示すという観察 ${ }^{55}$, 年) は後者の可能 性を支持するあのであろう.

一方, 神経分泌細胞に対する抑制性の神経経路には HPC の関与が考えられた．海馬刺激による LH の 分泌抑制はVelasco and Taleisnik ${ }^{56)}$ によって報告されており，Kawakami ら 29) あ，慢性実験では HPC 刺 激は血中 LH 亿影響を与えないが，本実験之同様の急性実験による HPC 刺激では下垂体からの性腺刺激 ホルモンの分泌を抑制すると述へてている，本実験では，てれら HPC 刺激によって抑制を受ける神経分泌細 胞の多くのあのが，同様に Ach によって抑制されたととから，一つの可能性として，HPC からの抑制経 路が Ach 作動性であることが考えられる. 動物の内分泌環境に伴う HPC の抑制効果が, 微小電気泳動投 与によるAch の効果と平行して変化を示し，DI で最あ顕著であったてとも，ての推論を支持するあのと 思われる. Ach 亿対する反応性が DI で最も高くなる機序についても，NE の場合と同様の可能性が想定さ れる. 視床下部の Ach 含量については合成, 代謝に関与する酵素活性が非発情期に発情期より高いという 観察がある ${ }^{332}$.

mAMYG の性腺刺激ホルモン分泌調節機能については，乙の部の電気刺激，電気化学刺激が排卵を誘発 するととが報告されており年）,311,583) 扁桃核が下垂体からの性腺刺激ホルモン分泌に促進的な役割を演じてい るととが推察される.しかし，一方では Conrey and de Groot ${ }^{4)}$ 以来，乙の領野が抑制野であるとの報告 あある．本実験では，電気刺激及び NE とAch の投与に際して，何れも共通に促進的反応を菍起する傾 向がうかがえたが，同時に，抑制を示す細胞群む無視できず，mAMYG から視床下部に至る系については 明確な結論を出すととができなかった。V Velasco and Taleisnik ${ }^{599}$ は扁桃核から視床下部への促進性神経伝 達物質を検討する目的でアトロピン及びレセルピンの投与を行ったが，何れす扁桃核の刺激効果には影響し なかったといい，Saul and Sawyer ${ }^{42)}$ は扁桃核刺激によるウサギの排卵はアトロピンで阻止されたがレセル ピンは無効であったと述べており，扁桃核から視床下部に至る系の性質については更に検討を加えるべき問 題であろう.

\section{結語}

正中隆起部に軸索を送る視床下部正中底部の神経分泌細胞の活動に対する脳内諸部位の電気刺激の効果を 調へ，乙れと薬物の微小電気泳動投与に対する反応から，それぞれの経路の化学的性質を考察した. 動物の 
内分泌環境による反応性の変化と, 薬物の第 3 脳室内投与が性腺刺激ホルモンの分泌動態に及ぼす影響を考 え併せると, 排畉促進性の MPO からの興奮の伝達はノルエピネフリン投与により, 抑制性の HPC からの 興奮伝達はアセチルコリン投与により模倣されるように思われた。ドーパミン投与の効果は, 本実験で調べ

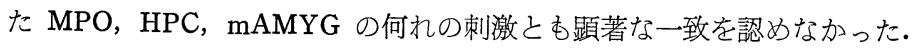

謝辟

稿を終るにあたり，御指導と御校閲を睗った川上正澄教授ならびに数々の御助言, 御教示を戴いた第 2 生理学教室 の皆様に深甚なる謝意を表します。 な扔本論文の一部は第 1 回神経内分泌ンンポジゥムに扔いて報告した.

\section{文献}

1) Ahrén, K. ; Fuxe, K. ; Hamberger, L., and Höckfelt, T. : Turnover changes in the tuberoinfundibular dopamine neurons during the ovarian cycle of the rat. Endocrinology $88: 1425-1424$, (1971). $\quad$ 2) Albe-Fessard, D. ; Stutinsky, F., and Liboubin, S. : Atlas Stéréotaxique du Diencéphale du Rat Blanc. (Editions du CNRS, Paris 1966). 3) Clemens, J.A. ; Shaar, C.J. ; Kleber, J. W., and Tandy, W. A. : Areas of the brain stimulatory to LH and FSH secretion. Endocrinology $88: 180-184$, (1971). $\quad$ 4) Conrey, K., and de Groot, J. : Limbic involvement in the regulation of luteinizing hormone release. Fed. Proc. $23: 109$, (1964). 5) Coppola, J.A. : Brain catecholamines and gonadotropin secretion. In Martini and Ganong (eds.) Frontiers in Neuroendocrinology, 1971 ; pp. 129-144, (Oxford University Press, New York 1971).

6) Coppola, J.A. ; Leonardi, R.G., and Lippmann, W. : Ovulatory failure in rats after treatment with brain norepinephrine depletors. Endocrinology $78: 225-228$, (1966). 7) Craven, R.P., and McDonald, P.G. : The effect of intrahypothalmic infusions of dopamine and noradrenaline on ovulation in reserpinetreated female rats. J. Endocrinol. $58: 319-326$, (1973). 8) Crighton, D.B. ; Schneider, H. P. G., and McCann, S. M. : Localization of LH-releasing factor in the hypothalamus and neurohypophysis as determined by an in vitro method. Endocrinology $87: 323-329$,

(1970). 9) Critchlow, V. : Ovulation induced by hypothalamic stmulation in the anestethized rat. Amer. J. Physiol. 195 : 171-174, (1958). 10) Curtis, D.R. : Microiontophoresis. In Nastuk (ed.) Physical Techniques in Biological Research. Vol. V. Electrophysiological Methods, Part A ; pp. 144-192, (Academic Press, New York 1958). 11) Curtis, D.R., and Koizumi, K. : Chemical transmitter substances in brain stem of cat. J. Neurophysiol. $24: 80-90$, (1961). 12) Everett, J.W., : Central neural control of reproductive functions of the adenohypophysis. Physiol. Rev. 44 : 373-431, (1964). $\quad$ 13) Everett, J.W., and Radford, H.M. : Irritative deposits from stainless steel electrodes in the preoptic rat brain causing release of pituitary gonadotropin. Proc. Soc. exp. Biol. Med. $108: 604-609$, (1961). 14$)$ Fuxe, K. : Cellular localization of monoamines in the median eminence and infundibular stem of some mammals. Acta physiol. scand. $58: 383-384$, (1963). 15) Fuxe, K. ; Höckfelt, T., and Jonsson, G. : Participation of central monoaminergic neurons in the regulation of anterior pituitary secretion. In Martini and Meites (eds.) Neurochemical Aspects of Hypothalamic Function; pp. 61-83, (Academic Press, New York 1970).

16) Halász, B., and Pupp, L. : Hormone secretion of the anterior pituitary gland after physical interruption of all nervous pathways to the hypophysiotropic area. Endocrinology $77: 553-562$,

(1965). 17) Harris, G.W. : Central control of pituitary secretion. In Field, Magoun and Hall (eds.) Handbook of Physiology, Section I, Vol. II ; pp. 1007-1038, (Amer. Physiol. Soc., Washington, D.C. 1960).

18) Hökfelt, T. : The possible ultrastructual identification of tubero- 
infundibular dopamine containing nerve endings in the median eminence of the rat. Brain Research 5 : 121-123, (1967). 19) Kalra, P.S. ; Kalra, S.P. ; Kruhlich, L. ; Fawcett, C.P. and McCann, S.M. : Involvement of norepinephrine in transmission of the stimulatory influence of progesterone on gonadotropin release. Endocrinology $90: 1168-1176$, (1970). 20) Kamberi, I.A. ; Mical, R.S., and Porter, J.C. : Luteinizing hormonereleasing activity in hypophysial stalk blood and elevation by dopamine. Science $166: 388-390$, (1969). $\quad 21)$ Kamberi, I.A. ; Mical, R.S., and Porter, J.C. : Effect of anterior pituitary perfusion and intraventricular injection of catecholamines and indolamines on LH release. Endocrinology $87: 1-12,(1970) . \quad 22)$ 川上正澄: 生理学的実験 法, 食智, 坂元, 鈴木 編, 現代産科婦人科大系 5 B 2 ; pp. 131-187, (中山書店, 東京 1974).

23) Kawakami, M., and Sakuma, Y. : Evidences for possible heterosynaptic inhibition of neuroendocrine cells in the median eminence. Neuroendocrinology, submitted for publication.

24) Kawakami, M. ; Seto, K., and Yoshida, K. : Influences of the limbic system on ovulation and on progesterone and estrogen formation in rabbit's ovary. Japan. J. Physiol. $16: 254-273$, (1966).

25) Kawakami, M., and Terasawa, E. : Effect of electrical stimulation of the brain on ovulation during estrous cycle in the rats. Endocrinol. japon. $17: 7-13$, (1970). 26) Kawakami, M., and Terasawa, E. : Acute effect of neural deafferentation on timing of gonadotropin secretion before proestrus in the female rat. Endocrinol. japon. $19: 449-459$, (1972). $\quad$ 27) Kawakami, M. ; Terasawa, E., and Ibuki, T. : Changes in multiple unit activity of the brain during the estrous cycle. Neuroendocrinology $6: 30-48$, (1970). $\quad 28$ ) Kawakami, M. ; Terasawa, E. ; Kimura, F., and Kubo, K. : Correlated changes in gonadotropin release and electrical activity of the hypothalamus induced by electrical stimulation of the hippocampus in immature and mature rats. In Lissak (ed.) Hormones and Brain Function; pp. 347-374, (Akadémiai Kiadó, Budapest 1973).

29) Kawakami, M. ; Terasawa, E. ; Kimura, F., and Wakabayashi, K. : Modulating effect of limbic structures on gonadotropin release. Neuroendocrinology $12: 1-16$, (1973). 30) 貴邑冨久子, 川上正澄：ラット海馬の性周期に及ぼす影響, 日本内分泌学会雑誌 $43: 1059$, (1968). 31) Koikegami, H. ; Yamada, T., and Usui, K. : Stimulation of amygdaloid nuclei and periamygdaloid cortex with special reference to its effects on uterine movements and ovulation. Folia psychiat. neurol. japon. $8: 7-31$, (1954). $\quad 32)$ Köves, K., and Halász, B. : Location of the neural structure triggering ovulation in the rat. Neuroendocrinology $6: 180-193,(1970) . \quad 33$ ) Libertun, C. ; Timiras, P.S., and Kragt, C.L. : Differences in the hypothalamic cholinergic system before and after puberty : inductory effect of testosterone. Neuroendocrinology $12: 73-85$, (1973).

34) Lichtensteiger, W. : Cyclic variations of catecholamine content in hypothalamic nerve cells during the estrous cycle of the rat, with a concomitant study of the substantia nigra. J. Pharmacol. exp. Ther. $165: 204-215$, (1969). $\quad 35)$ Markee, J.E. ; Everett, J.W., and Sawyer, C.H. : The relationship of the nervous system to the release of fonadotropin and the regulation of the sex cycle. Recent Progr. Hormone Res. 7 : 139-163, (1952). $\quad 36$ ) McCann, S.M. ; Kalra, P.S. ; Donoso, A.O. ; Bishop, W. ; Schneider, H.P.G. ; Fawcett, C.P., and Krulich, L. : The role of monoamines in the control of gonado-tropin and prolactin secretion. In Knigge, Scott, and Weindl (eds.) Brain-Endocrine Interaction. Median Eminence : Structure and Function; pp. 224-235, (Karger, Basel 1972). $\quad 37$ ) Moss, R.L. ; Urban, I., and Cross, B.A. : Microelectrophoresis of cholinergic and aminergic drugs on paraventricular neurones. Amer. J. Physiol. 223 : 310-318, (1972). 38) Nauta, W.J.H. : An experimental study of the fornix system in the rat. J. comp. Neurol. $104: 247-272$, (1956).

39) Niswender, G.D. ; Midgley, A.R. ; Monroe, S.E., and 
Reichert, L.E. : Radioimmunoassay for rat luteinizing hormone with antiovine LH serum and ovine LH-131 I. Proc. Soc. exp. Biol. Med. $128: 807-811$, (1968).

40) Rubinstein, L., and Sawyer, C.H. : Role of catecholamines in stimulating the release of pituitary ovulatory hormone (s) in rats. Endocrinology 86 : 988-995，(1970). 41）佐久間康夫 : 視床下部神経分泌細胞における放出ホルモ ンの分泌調節機序にする研究, (I) 神経分泌細胞の電気生理学的特性と体液性調䬣について, 日本内分泌学 会雑誌52：1-20，(1976). 42) Saul, G.D., and Sawyer, C.H. : Atropine blockade of electrically induced hypothalamic activation of the rabbit adenohypophyses. Fed. Proc. $16: 112$, (1957).

43) Sawyer, C.H. ; Critchlow, B.V., and Barraclough, C.A. : Mechanism of blockade of pituitary activation in the rat by morphine, atropine and barbiturates. Endocrinology $57: 345-354$, (1955).

44) Sawyer, C.H. ; Everett, J.W., and Markee, J.E. : A neural timing factor in the mechanism by which estrogen induces the release of luteinizing hormone in the rat. Endocrinology $44: 218-233$, (1949). 45) Sawyer, C.H. ; Hilliard, J. ; Kanematsu, S. ; Scaramuzzi, R., and Blake, C.A. : Effects of intraventricular infusions of norepinephrine and dopamine on $\mathrm{LH}$ release and ovulation in the rabbit. Neuroendocrinology $15: 328-337$, (1974). 46) Sawyer, C.H. ; Markee, J.E., and Tawnsend, B.F.: Cholinergic and adrenergic components in the neuro-humoral control of the release of LH in the rabbit. Endocrinology $44: 18-37$, (1974). 47) Schneider, H.P.G., and McCann, S.M. : Possible role of dopamine as transmitter to promote discharge of LH-releasing factor. Endocrinology $85: 121-132$, (1969). 48) Schneider, H.P.G., and McCann, S.M. : Release of $\mathrm{LH}$-releasing factor (LRF) into the peripheral circulation of hypophysectomized rats by dopamine and its blockade by estradiol. Endocrinology $87: 249-254$, (1970). 49$)$ Schwarz, N.B., and McCormack, C.E. : Reproduction : gonadal function and its regulation. Ann. Rev. Physiol. 34 : 425-472, (1972). $\quad 50)$ Szentágothai, J. ; Flerkó, B. ; Mess, B., and Halász, B. : Hypothalamic Control of the Anterior Pituitary. (Akadémiai Kiadó, Budapest 1962).

51) Tasaki, K. ; Tsukahara, Y. ; Ito, S. ; Wayner, M.J., and Yu, W.Y. : A simple, direct and rapid method for filling microelectrodes. Physiol. Behav. $3: 1009-1010$, (1968). 52) Tejasen, T., and Everett, J.W. : Surgical analysis of the preopticotuberal pathway controlling ovulatory release of gonadotropins in the rat. Endocrinology $81: 1387-1396$, (1967). 53) 寺沢 螢: 排卵の中枢機序に関する研究 (I), 連続発情ラッテにおけを排卯ホルモン放出時の脳活動に関する研究, 日本内分泌学会雑誌, $46: 1081-1096$, (1971). 54) Terasawa, E., and Sawyer, C.H. : Changes in electrical activity in the rat hypothalamus related to electrical stimulation of adenohypophyseal function. Endocrinology $85: 143-149$, (1969). 55) Tima, L., and Flerkó, B. : Ovulation induced by norepinephrine in rats made anovulatory by various experimental procedures. Neuroendocrinology $15: 346-354$, (1974).

56) Velasco, M.E., and Taleisnik, S. : Effect of hippocampal stimulation on the release of gonadotropin. Endocrinology $85: 1154-1159$, (1969). 57) Velasco, M.E., and Taleisnik, S. : Release of gonadotropins induced by amygdaloid stimulation in the rat. Endocrinology $84: 132-139$, (1969). 58) Wurtman, R.J. : Brain catecholamines and the control of secretion from the anterior pituitary gland. In Meites (ed.) Hypophysiotropic Hormones of the Hypothalamus : Assay and Chemistry; pp. 184-194, (Williams and Wilkins, Baltimore 1970). 